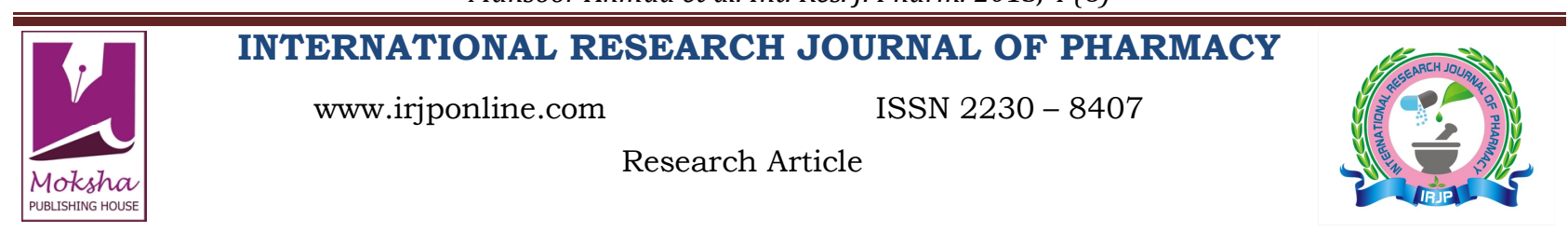

\title{
EFFECTS OF THYROID DYSFUNCTION ON SYSTOLIC OR DIASTOLIC BLOOD PRESSURE, PULSE RATE, SERUM CREATININE AND LIVER ENZYMES
}

\author{
Mansoor Ahmad ${ }^{*}$, S. Mahboob Alam², Salman Habib ${ }^{3}$, Mehjabeen $^{4}$, Noor Jahan ${ }^{5}$ \\ ${ }^{1}$ Research Institute of Pharmaceutical Sciences, Department of Pharmacognosy, University of Karachi, Karachi, Pakistan \\ ${ }^{2}$ BMSI, Jinnah Postgraduate Medical Center, Karachi, Pakistan \\ ${ }^{3}$ Department of Nuclear Medicine, Karachi Institute of Radiotherapy and Nuclear medicine (KIRAN), Karachi, Pakistan \\ ${ }^{4}$ Department of Pharmacology, Federal Urdu University for Arts, Science and Technology, Gulshan-e-Iqbal Campus, Karachi, \\ Pakistan \\ ${ }^{5}$ Dow College of Pharmacy, Dow University of Health Sciences, Ojha Campus, Karachi, Pakistan \\ *Corresponding Author Email: mehjbn1@gmail.com
}

Article Received on: 20/06/13 Revised on: 01/07/13 Approved for publication: 16/08/13

DOI: $10.7897 / 2230-8407.04820$

IRJP is an official publication of Moksha Publishing House. Website: www.mokshaph.com

(C) All rights reserved.

\section{ABSTRACT}

Thyroid disorder is very common in Pakistani population and most of the patients either sex having thyroid problems which may disturb various body systems for example variation in systolic / diastolic blood pressure, pulse rate, serum creatinine level and ALT / SGPT (Alanine Aminotransferase) and AST / SGOT (Aspartate Aminotransferase) levels. The purpose of our study is to determine the effects of thyroid dysfunction on blood pressure, pulse rate, renal and liver functions and there correlation with thyroid status before and after treatment in patients with hypo and hyperthyroidism respectively. The results showed that there are significant differences in the levels of biochemical parameters (Serum Creatinine, ALT, AST, FT3, FT4 and TSH) as compared to normal in both groups. Significant changes were also found in blood pressure and pulse rate of both male and female groups.

Keywords: hyperthyroidism, hypothyroidism, liver enzymes, blood pressure

\section{INTRODUCTION}

The thyroid hormones play important role in human body. Therefore, different research studies carried out on this aspect world wide ${ }^{1}$.

Thyroid disorders are amongst the most prevalent of medical conditions. Their manifestations vary considerably from area to area and are determined principally by the availability of iodine in the diet. Epidemiological studies of thyroid dysfunction have limitations, for example the definition of overt hypothyroidism and subclinical hypothyroidism, the selection criteria of the sample used, the influence of age, sex, genetic and environmental factors and the different techniques used for the measurement of thyroid hormones and the relative rareness of incidence data ${ }^{2}$. Data on the involvement of liver enzymes and serum creatinine with thyroid abnormalities are also limited. In our study it has been calculated from newly diagnosed untreated patient from short follow-up studies (3 months).

\section{MATERIAL AND METHODS \\ Collection of the Sample}

About 110 blood samples from patients suffering with Patients with newly diagnosed primary hypothyroidism who had been referred to the Division of Endocrinology and cardiovascular at KIRAN hospital Karachi, Pakistan between January 2011 and February 2013 were included in this study. A consent form was obtained from all patients. 42 blood samples were collected from healthy individuals at different age group. The excluded criteria in this study were patients with thyroid cancer, neoplastic disease and secondary hypothyroidism.

\section{Reagents and Chemicals}

The necessary kits and chemicals were obtained from international companies. Ready-made reagents were purchased from Merck and Scharlau for Biochemical parameters such as ALT, AST and Serum creatinine and were estimated as per standard procedure. Thyroid hormonal imbalances like Thyrotropin (TSH), Triiodothyronine $\left(\mathrm{T}_{3}\right)$, Thyroxine $\left(\mathrm{T}_{4}\right)$ in serum were detected using RIA test. Serum creatinine, SGOT / AST, SGPT / ALT were assayed by following the recommended Laboratory protocol. Physical parameters such as pulse rate, systolic and diastolic blood pressure were also measured.

\section{Statistical Analysis}

Statistical analysis was performed by using ' $Z$ ' test at $0.05 \%$ level of significance. The results were calculated as mean \pm SEM.

\section{RESULTS}

The results of male and female groups of hyperthyroidism and hypothyroidism were presented in Table 1,2 and Graph 1, 2. There was significant difference in the levels of biochemical parameters (Serum Creatinine, ALT, AST, FT3, FT4, and TSH as compared to normal in both groups. Significant changes were also found in blood pressure and pulse rate of both male and female groups. In male hyperthyroid group (diagnosed) SGOT and serum creatinine were slightly decreased where as in male and female hypothyroid groups (diagnosed) were increased respectively. In female hyperthyroid group only serum creatinine was decreased. Blood pressure and pulse rate were increased in both groups of diagnosed hyperthyroid and decreased in hypothyroid male and female groups. Mean differences in control and diagnosed groups of both hyperthyroidism and hypothyroidism were comparable but there was no significant difference observed with respect to blood pressure and pulse rate in between groups (Graph 1,2). It was also observed that in diagnosed male hypothyroid group serum creatinine level was increased $(2.12 \pm 0.06)$ significantly as compared to female group $(1.72 \pm 0.05)$. 
Mansoor Ahmad et al. Int. Res. J. Pharm. 2013, 4 (8)

Table 1: Different Biochemical Parameters for Male in Hyper and Hypothyroidism Before and After Treatment

\begin{tabular}{|c|c|c|c|c|c|c|}
\hline $\begin{array}{c}\text { Groups } \\
\text { Reference range Units }\end{array}$ & \multicolumn{5}{|c|}{ Biochemical Parameters } \\
\cline { 2 - 7 } & SGPT / ALT & SGOT / AST & Serum Creatinine & FT3 & FT4 & TSH \\
\cline { 2 - 7 } & $10-40 \mathrm{U} / 1$ & $10-30 \mathrm{U} / 1$ & $0.5-1.01 \mathrm{mg} / \mathrm{dl}$ & $1.78-3.77 \mathrm{ng} / 1$ & $0.77-1.86 \mathrm{ng} / 1$ & $0.17-4.05 \mathrm{U} / 1$ \\
\hline Control (20) & $27.4 \pm 2.13$ & $17.2 \pm 1.37$ & $0.68 \pm 0.06$ & $2.50 \pm 0.05$ & $1.02 \pm 0.03$ & $273 \pm 0.81$ \\
\hline Diagnosed Hyperthyroid & $13.68 \pm 1.52$ & $9.24 \pm 1.87$ & $0.44 \pm 0.10$ & $4.98 \pm 0.04$ & $2.17 \pm 0.07$ & $0.041 \pm 0.45$ \\
\hline Treated Hyperthyroid & $22.31 \pm 1.21$ & $15.6 \pm 1.27$ & $0.52 \pm 0.06$ & $2.23 \pm 0.05$ & $1.74 \pm 0.03$ & $1.45 \pm 0.81$ \\
\hline Diagnosed Hypothyroid & $47.6 \pm 2.21$ & $34.7 \pm 1.87$ & $2.12 \pm 0.06$ & $0.80 \pm 0.04$ & $0.47 \pm 0.03$ & $77.95 \pm 0.81$ \\
\hline Treated Hypothyroid & $39.6 \pm 1.83$ & $27.2 \pm 1.87$ & $1.0 \pm 0.06$ & $1.45 \pm 0.04$ & $0.74 \pm 0.05$ & $45.1 \pm 0.72$ \\
\hline
\end{tabular}

Results are expressed in Mean \pm SEM, $\mathrm{p}<0.05$ Control: $\mathrm{N}=42$ (Male 24, Female 31), Hyperthyroid 55 (Male 24, Female 31), Hypothyroid 55(Male 24,

Female 31), Average age: 38 (23-53)

Table 2: Different Biochemical Parameters for Female in Hyper and Hypothyroidism Before and After Treatment

\begin{tabular}{|c|c|c|c|c|c|c|}
\hline \multirow{2}{*}{ Groups } & \multicolumn{5}{|c|}{ Biochemical Parameters } \\
\cline { 2 - 7 } Reference range Units & SGPT / ALT & SGOT / AST & Serum Creatinine & FT3 & FT4 & TSH \\
\cline { 2 - 7 } & $10-40 \mathrm{U} / 1$ & $10-30 \mathrm{U} / 1$ & $0.5-1.01 \mathrm{mg} / \mathrm{dl}$ & $1.78-3.77 \mathrm{ng} / 1$ & $0.77-1.86 \mathrm{ng} / 1$ & $0.17-4.05 \mathrm{U} / 1$ \\
\hline Control (22) & $28.6 \pm 1.13$ & $18.2 \pm 1575$ & $0.78 \pm 0.03$ & $2.21 \pm 0.04$ & $1.23 \pm 0.05$ & $2.45 \pm 0.61$ \\
\hline Diagnosed Hyperthyroid & $13.8 \pm 1.83$ & $9.3 \pm 1.47$ & $0.39 \pm 0.07$ & $4.91 \pm 0.03$ & $2.18 \pm 0.06$ & $0.054 \pm 0.54$ \\
\hline Treated Hyperthyroid & $17.2 \pm 2.14$ & $13.3 \pm 1.77$ & $0.51 \pm 0.04$ & $3.65 \pm 0.05$ & $1.85 \pm 0.06$ & $1.34 \pm 0.75$ \\
\hline Diagnosed Hypothyroid & $44.3 \pm 1.42$ & $35.8 \pm 1.17$ & $1.72 \pm 0.05$ & $0.82 \pm 0.15$ & $0.54 \pm 0.05$ & $78.3 \pm 0.41$ \\
\hline Treated Hypothyroid & $32.3 \pm 2.03$ & $27.3 \pm 1.27$ & $1.02 \pm 0.05$ & $1.89 \pm 0.05$ & $0.81 \pm 0.03$ & $15.8 \pm 0.61$ \\
\hline
\end{tabular}

Results are expressed in Mean \pm SEM, p < 0.05 Control: N = 42 (Male 24, Female 31), Hyperthyroid 55 (Male 24, Female 31), Hypothyroid 55(Male 24, Female 31), Average age: 38 (23-53)

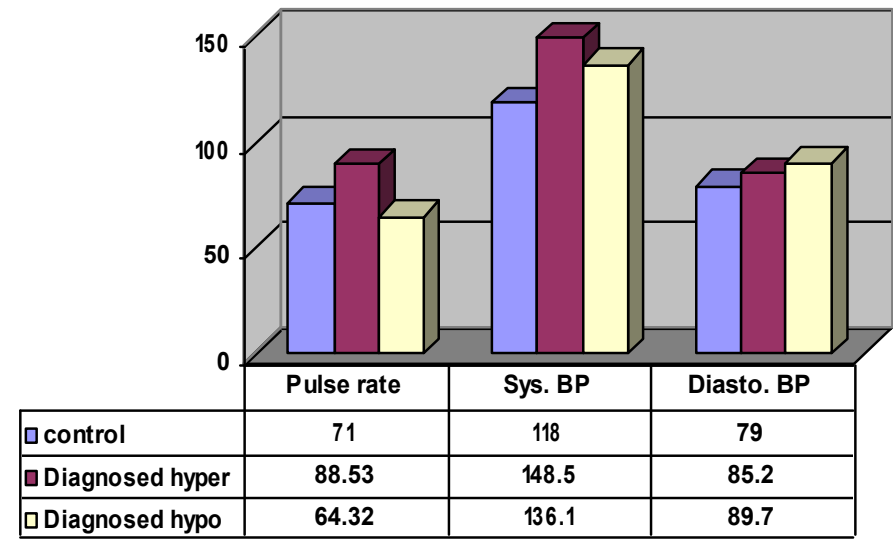

口control $\square$ Diagnosed hyper aDiagnosed hypo

Graph 1: Effect of Thyroid Dysfunction on Pulse rate, Systolic and Diastolic Blood Pressure in Male Group

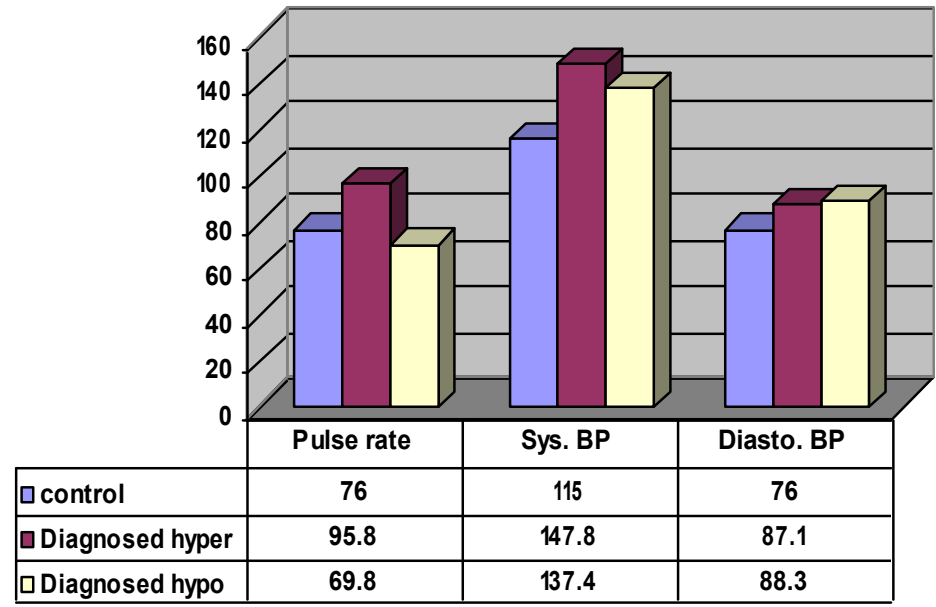

口control $\square$ Diagnosed hyper $\square$ Diagnosed hypo

Graph 2: Effect of Thyroid Dysfunction on Pulse rate, Systolic and Diastolic Blood Pressure in Female Group 
DISCUSSION

Thyroid dysfunction is associated with changes in serum creatinine. In agreement with reported study ${ }^{1}$, serum creatinine values in our study were higher in hypothyroidism and lower in hyperthyroidism as compared with the values of the same individual in the euthyroid state ${ }^{5}$. In case of low serum creatinine level there was a decreased in muscle mass and results in muscular weakness, dystrophy and poor physical activity. However, elevated serum creatinine level in hypothyroid state results in decreased GFR but not related with altered creatnine kinase levels ${ }^{6}$. The present findings indicated that increased serum creatinine levels during hypothyroid disease can be easily developed and more significantly increased in male group. This may be due to the impaired glycogenolysis and mitochondrial oxidative metabolism ${ }^{7}$. Significant changes in glomerular and tubular functions and elcetrolyte disbalance were found in thyroid dysfunction. It was also observed that pulse rate and blood pressure were reduced in hypothyroidism. Since hypothyroidism is associated with reduction in GFR therefore results in hyponatremia and reduction in blood pressure ${ }^{8}$. Similarly low thyroid level increased the liver enzymes (Table 1,2). Since in hypothyroidism utilization of glucose for energy is decreased and body starts utilizing fat and proteins. Therefore, that causes an increase in liver enzymes ${ }^{9-}$ ${ }^{10}$. It was also observed that after treatment these abnormalities were found reversed ${ }^{11-13}$. But the problems associated with cardiac dysfunctioning are directly related with the increased or decreased level of thyroid hormone. Since calcium activated ATPase have involvement in regulation of cardiac functions which is directly affected by altered thyroid hormone levels. Therefore, change in blood pressure and pulse rate was observed in this study ${ }^{14-15}$. More over different studies have shown that kidney dysfuntioning in hypothyroidism can increased PVR (peripheral vascular resistant) and decreased in myocardial contraction and hyperlipidemaia ${ }^{16-17}$. So in most of the hypothyroid patient weight gain was observed. In this study increased level of thyroid hormone results in increased in blood pressure. This may be due to the activation of rennin angiotensin system and increased $\mathrm{T}_{3}$ level which increased the synthesis of RBCs by activation of erythropoietin ${ }^{17}$.

\section{CONCLUSION}

From this study it can be concluded that the cardiac functions and body homeostasis were changed in altered thyroid hormone levels and have significant effect on the life style of affected person. Although liver enzymes were returned to the normal limits but continuous screening is necessary for dose adjustment and monitoring of metabolic functions.

\section{REFERENCES}

1. Park SM, Chatterjiee VKK. Genetics of congenital hypothyroidism. Med Genet 2005; 42: 379-389. http://dx.doi.org/10.1136/ jmg.2004. 024158 PMid:15863666 PMCid:PMC1736062

2. Vanderpump MPJ. The epidemiology of thyroid diseases. In: Braverman LE, Utiger RD, eds. Werner and Ingbar's The Thyroid: A Fundamental and Clinical Text. $9^{\text {th }}$ ed, JB Lippincott-Raven, Philadelphia; 2005. p. 398-406.

3. Maxwell DB, Fisher EA, Ross Clinics HA, and Estep HL. Serum alkaline phosphatase in diabetes mellitus. Journal of the American College of Nutrition 1986; 5(1): 55-59. PMid:3700883

4. Lalitha B, Sairam CVS, Ushakiranmayi G, Sudhakar P, Vijetha P. Comparative Study of Oxidative Stress, Clinical Complications and Incidence of Type-II Diabetics in Different Age Groups. Int J Med Res 2010; 1(1): 59-67.

5. Fricker M, Wiesli P, Brandle M, Schwegler B and Schmid C. Impact of thyroid dysfunction on serum cystatin C. Kidney International 2003; 63: 1523-1755. http://dx.doi.org/10.1046/j.1523-1755.2003.00925.x PMid: 12675875

6. Lin HH, Tang MJ. Thyroid hormone up regulates Na,K-ATPase alpha and beta mRNA in primary cultures of proximal tubule cells. Life Sci 1997; 60: 375-82. http://dx.doi.org/10.1016/S0024-3205(96)00661-3

7. Den Hollander JG, Wulkan RW, Mantel MJ, Berghout A. Correlation between severity of thyroid dysfunction and renal function. Clin Endocrinol (Oxf) 2005; 62: 423-7. http://dx.doi.org/10.1111/j.13652265.2005.02236.x PMid: 15807872

8. Katz AI, Lindheimer MD. Renal sodium and potassium-activated adenosine triphosphatase and sodium re absorption in the hypothyroid rat. J Clin Invest 1973; 52: 796-804. http://dx.doi.org/10.1172/ JCI107243 PMid:4348343 PMCid:PMC302326

9. Celsing F, Blomstrand E, Melichna J, Terrados N, Clausen N, Lins PE, et al. Effect of hyperthyroidism on fiber-type composition, fiber area, glycogen content and enzyme activity in human skeletal muscle. Clin Physiol 1986; 6: 171-81. http://dx.doi.org/10.1111/j.1475-097X.198 6.tb00066.x PMid:2937605

10. Dang AQ, Faas FH, Carter WJ. Influence of hypo- and hyperthyroidism on rat liver glycerophospholipid metabolism. Lipids 1985; 20(12): 897902. http://dx.doi.org/10.1007/BF02534774 PMid:4094520

11. Youssef WI, Mullen KD. The liver in other (nondiabetic) endocrine disorders. Clin Liver Dis 2002; 6: 879-8. http://dx.doi.org/10.1016 /S1089-3261(02)00049-1

12. Shimada $T$, Higashi $K$, Umeda $T$, Sato $T$. Thyroid functions in patients with various chronic liver diseases. Endocrinol Jpn 1988; 35: 357-69. http://dx.doi.org/10.1507/endocrj1954.35.357 PMid:3143545

13. Soylu A, Taskale MG, Ciltas A, Kalayci M, Kumbasar AB. Intra hepatic cholestasis in subclinical and overt hyperthyroidism: two case reports. J Med Case Rep 2008; 2: 116. http://dx.doi.org/10.1186/1752-1947-2-116 PMid:18426598 PMCid:PMC2365967

14. Kharoubi O, Slimani M, Aoues A, Seddik L. Prophylactic effects of Worm wood on lipid peroxidation in an animal model of lead intoxication. Indian J Nephrol 2008; 18(2): 51-57. http://dx.doi.org/ 10.4103/0971-4065.42333 PMid:20142903 PMCid:PMC2813123

15. Mark PJ Vanderpump. Thyroid international. edited by: Peter PA Smyth, UCD, Dublin published by: Merck KGaA, Germany; Darmstadt; 2009.

16. Gharib H, Tuttle RM, Baskin HJ, et al. Subclinical thyroid dysfunction: A joint statement on management from the American Association of Clinical Endocrinologists, the American Thyroid Association and the Endocrine Society. J Clin Endocrinol Metab 2005; 90(1): 581-585. http://dx.doi.org/10.1210/jc.2004-1231 PMid:15643019

17. Biondi B, Klein I. Hypothyroidism as a risk factor for cardiovascular disease. Endocrine 2004; 24(1): 1-13. http://dx.doi.org/10.1385/ ENDO:24:1:001

Cite this article as:

Mansoor Ahmad, S. Mahboob Alam, Salman Habib, Mehjabeen, Noor Jahan. Effects of thyroid dysfunction on systolic / diastolic blood pressure, pulse rate, Serum creatinine and liver enzymes. Int. Res. J. Pharm. 2013; 4(8):117-119 http://dx.doi.org/10.7897/2230-8407.04820 